INTERNATIONAL JOURNAL OF MULTIDISCIPLINARY RESEARCH AND ANALYSis

ISSN(print): 2643-9840, ISSN(online): 2643-9875

Volume 04 Issue 10 October 2021

DOI: 10.47191/ijmra/v4-i10-03, Impact Factor: 6.072

Page No.- 1361-1369

\title{
Effect of Exchange Rate Fluctuation and Foreign Reserves on Macroeconomic Performance in Nigeria
}

\author{
Nkire Nneamaka Loretta ${ }^{1}$, Atayi Abraham Vincent ${ }^{2}$, Ibukun Felix Olusegun (PhD) ${ }^{3}$, \\ Ogunbiyi Ayoola Olayinka(PhD) ${ }^{4}$ \\ ${ }^{1,2}$ Department of Economics, Afe Babalola University, Ado Ekiti, Nigeria \\ ${ }^{3,4}$ Department of Banking and Finance, Afe Babalola University, Ado Ekiti
}

\begin{abstract}
This study examines the effect of Exchange Rate Fluctuation and Foreign Reserves on Macroeconomics Performance in Nigeria from 1980-2019. The variables of interest include External Debt, Reserves, Exchange Rate, External Debt Servicing and Government Expenditure were analyzed using co-integration, auto-redistribution lag model (ARDL) and Granger Causality test to understand the long and short run relationship between the variables. Result revealed that there is a unidirectional relationship between foreign reserves and the exchange rate. Exchange rate Granger causes foreign reserves in Nigeria, while foreign reserves do not granger cause exchange rate Granger. This means that as the exchange rate depreciates or appreciates, it always has an impact on Nigeria's foreign reserves. The study recommends among other thing that the government should ensure that the country's foreign reserves are used and managed efficiently. This is because it has been established that foreign reserves have a beneficial impact on macroeconomic performance and stimulate economic growth both of which help to enhance the Nigerian economy.
\end{abstract}

KEYWORDS: Exchange Rate, Foreign Reserves, Granger Causality and Nigeria.

\section{INTRODUCTION}

Interest rates in the economy, capital inflows, inflation rates, current account balances, volume of foreign exchange reserves, GDP growth rate, fiscal deficit, export to GDP ratios, and import to GDP ratios, political stability, development indices, and corruption are some of the factors that can influence exchange rate fluctuations (Raju \& Gokhale, 2013). Central banks that rigorously prohibit foreign exchange interventions are generally aware of the volatility of the foreign exchange markets and may implement interventionist strategies to counteract potentially disruptive short-term swings (Kalu, Ugwu, Ndubuaku \& Ifeanyi, 2019).

The price of crude oil on the worldwide market has fluctuated over the years. As a result, Nigeria's external reserves have fluctuated, affecting the naira's exchange rate value. Following the adoption of the Structural Adjustment Program (SAP) and the consequent deregulation of the foreign exchange market, which resulted in the establishment of the Secondtier Foreign Exchange Market in 1986, exchange rate instability became prevalent in the mid-1980s, particularly in 1986. (SFEM). Because exchange rate floatation usually affects the economy by preventing price stability, central banks frequently interfere in foreign exchange markets to enforce stability. Depending on the state of the economy, the process usually involves buying and selling to keep the domestic currency's value stable.

With the growing popularity of the managed floating exchange rate system in some countries, the relationship between the quantity of foreign exchange reserves maintained by the Central Bank and the exchange rate has become a crucial topic in the context of monetary policy intervention by central banks. The exchange rate under a managed float exchange rate system is governed by the relationship between currency demand and supply. This suggests that exchange rate changes are caused by excess demand or a decline in currency supply. When a country's currency rate fluctuates, the central bank will intervene in the foreign exchange market by buying excess foreign exchange or selling foreign exchange to meet market demand (Bayat, Mehmet \& Selim, 2014).

In Nigeria, the subject of currency rate swings has become a hot topic. This is owing to the fact that maintaining a stable rate of exchange is the goal of every economy. However, despite the fact that Nigeria weakened its currency in order to encourage exports 


\section{Effect of Exchange Rate Fluctuation and Foreign Reserves on Macroeconomic Performance in Nigeria}

and stable the exchange rate, this goal has proven difficult to achieve. According to Onwuka and Igwezea (2014), the problems in Nigeria's foreign exchange market are mostly due to an imbalance between supply and demand for foreign currency.

Reserves (also known as international reserves, foreign reserves, or foreign exchange reserves) are assets kept by a country's monetary authority or central bank that are denominated in a foreign currency. Foreign reserves are a country's external assets, which include Special Drawing Rights (SDRs), gold, bonds, and foreign currency deposits held by the country's monetary authority or central bank. International reserves, according to the International Monetary Fund, are those external assets that are readily available to monetary authorities and under their control for the purposes of intervening in the exchange rate market to manage the currency exchange rate, meeting balance of payments financing needs, and other related purposes (IMF, 2014). The importance of accumulating external reserves in any economy's growth process cannot be overstated. The reasons for countries accumulating external reserves have varied greatly across the globe. Reserves are kept, according to the International Monetary Fund (IMF), to finance balance of payment (BOP) disequilibrium as well as to maintain a competitive exchange rate level capable of meeting macroeconomic goals. Reserves also serve as a monetary policy tool and a liquidity buffer in the event of a global financial market crash, as an indirect collateral that protects foreign direct investment, and as an instrument for mitigating the risks of external factors in the process of restoring confidence and improving financial market stability during times of financial turmoil (Nwosa, 2013).

Despite this, most emerging economies, including Nigeria, have continued to build up their foreign reserves. Nigeria's foreign reserve accumulation has been expanding, according to statistics from the World Bank dataset. In the 1970s, Nigeria's foreign exchange reserves grew in response to the commercial discovery of oil, which was accompanied by an increase in crude oil prices on the international market. Foreign reserves increased steadily from 1981 to 2003. It began to rise sharply in 2003 and peaked in 2008, with a value of around $\$ 53$ billion. The rise in crude oil prices during that time period is responsible for the price increase. Following that, it fell to its lowest point since its high in 2008 in 2016. Following that, it continued to rise, but in 2019 it fell somewhat to $\$ 38$ billion, down from over $\$ 43$ billion the previous year.

Despite continuous cycles of economic booms and busts, the Nigerian economy has consistently relied on oil as its primary source of foreign exchange earnings since the 1970s. According to the World Bank (2014), mono-product economies, particularly those that rely on oil, will remain vulnerable due to global oil price volatility. Nigeria's capital account is subject to crude oil price changes due to its reliance on oil for over $90 \%$ of its foreign exchange revenues. This, combined with the country's high rate of imports, contributed to oscillations in the amount of foreign reserves acquired over time, as well as the management of those reserves (Nwachukwu, Ali, Abdullahi, Shettima, Zirra, Falade, and Alenyi, 2016). The spectacular increase in Nigeria's foreign reserves, particularly between 2003 and 2008, sparked a lot of discussion and interest among the general public about how the reserves should be maintained and how to ensure that the trend continues. While some criticized the government and monetary authorities for hoarding reserves in the face of poverty and unemployment, they advocated for the reserves to be injected into the economy to create jobs and develop infrastructure. Others, on the other hand, believed that because the reserves were accumulated through extremely volatile and unsustainable sources, the excess revenue should be reinvested in the economy (Igbanugo \& Eze, 2017). Most Low Income Countries (LICS) and Least Developed Countries (LDCs) rely on aid and donations to supplement their reserves. As a result, a central bank can manipulate and manage the level of foreign reserve to prevent or limit volatility in a country's exchange rate. The central bank manages and coordinates internal and external economic stability through the use of foreign reserves by intervening in the foreign currency market. This act increases worldwide competitiveness, boosts economic progress, and fosters entrepreneurial development. In Nigeria, the Central Bank monitors capital outflows and supports capital inflows with the goal of building up external reserves (Folorunsho, Ajisafe \& Olofin, 2019).

The level of the country's foreign exchange reserves has fluctuated consistently over time. The drop in foreign exchange reserves is owing to a large reduction in foreign exchange inflow into the country, which has been triggered by the persistent drop in crude oil prices. Nigeria's macroeconomic stability has been jeopardized by the drop in reserves. Despite the fact that reserves have fluctuated over the years, the exchange rate has risen. Crude oil prices, foreign reserves, and the currency rate have all experienced significant volatility, raising the question of whether there is a causal relationship between them. Furthermore, the Central Bank now has lesser reserves, making effective intervention in the foreign exchange market to maintain exchange rate stability a challenge.

\section{LITERATURE REVIEW}

According to Richard (2018), goods and services sold and rendered in international business must be paid for, and payments for these goods and services are usually made in different currencies. As a result, both the seller and the buyer must agree on a basis of conversion. For the currencies involved, this is known as the exchange rate. The method by which one currency is converted into another is referred to as an exchange rate. Ceteris paribus, this rate also reflects the strength of the economy of that country. 


\section{Effect of Exchange Rate Fluctuation and Foreign Reserves on Macroeconomic Performance in Nigeria}

Any currency that isn't a country's native currency is referred to as foreign. It is the mathematical representation of the international medium of exchange, which is a method of settling foreign accounts or debts arising from international economic activities. The price per unit of a country's currency quoted in terms of another currency is also referred to as the exchange rate. It is the quantitative representation of a country's currency in terms of another country's currency. The price of one unit of a currency in terms of another currency is commonly used to define an exchange rate. It's also known as the value of a foreign currency in terms of a domestic currency, i.e. how much one currency is worth in terms of another.

Various studies in industrialized economies have found that creating an optimal exchange rate is one of the most significant variables necessary for economic growth and development. This is because the choice of an improper exchange rate, or the constant observation of exchange rate fluctuation, has been a key obstacle for most African economies, including Nigeria's, in terms of economic progress. According to Osuka and Osuji (2008), Nigerian monetary authorities have been grappling with the issue of maintaining both internal and external rate of exchange balances since 1960 in order to reduce poverty, raise the standard of living, accelerate economic growth, and maintain political stability. They have, on the other hand, used administrative powers to tinker with the domestic economic buttons of exchange rates. As a result of this action, the Nigerian currency, the naira, has continued to depreciate against the US dollar.

Foreign exchange reserves are foreign currency deposits held by the central bank or other monetary authorities, according to the International Monetary Fund (IMF) (2009). The euro, the dollar, the pound sterling, and the yen are all examples of foreign reserves maintained by central banks. These reserves are used to underpin the central bank's liabilities, such as the domestic and local currency it issues, as well as deposits held by various Deposit Money Banks (DMBs), the government, and other financial organizations. The central banks of each country use foreign reserves to support their monetary and foreign exchange policies in order to maintain currency stability. Foreign reserves are also known as a country's external assets, which include SDRs, gold, bonds, and foreign currency deposits held by a country's monetary authority or central bank. International reserves, according to the International Monetary Fund, are those external assets that are readily available to monetary authorities and that they control for the purposes of intervening in the exchange rate market to manage the currency exchange rate, meeting balance of payments financing needs, and other related purposes (IMF, 2014).

Macroeconomic performance is a measure of how well a country or a nation is performing in relation to the government's specified goals. Any macroeconomic policy should aim to increase economic growth, price stability, balance of payments balance, and full employment. Job creation, price stability, balance of trade, economic growth, factor resource efficiency, environmental stability, income and wealth redistribution, and infrastructure development are all factors that macroeconomic policies typically consider (Riley, 2010). Changes in policies or events in other countries often have an impact on a country's macroeconomic performance. Economic growth, inflation rate, unemployment, government spending, national debt, current account balance, investment, exchange rate, poverty level, human development index (which includes education, health, and other areas), trade (imports and exports), interest rate, and labor productivity are some of the major macroeconomic performance indicators.

\section{Exchange Rate in Nigeria}

Any exchange rate policy's goal is to determine an optimal rate of exchange while also preserving its stability. Over the years, efforts have been made to fulfill these goals and establish efficiency in the foreign currency market by employing a variety of ways. Exchange rate arrangements in Nigeria have evolved from a fixed exchange rate regime in the 1960s to a pegged exchange rate regime in the 1970s and 1980s, and finally to various forms of the floating exchange rate regime adopted in 1986 following the adoption of the Structural Adjustment Program (Dada \& Oyeranti, 2012).

Foreign exchange was earned by private sector businesses prior to the passage of the Exchange Control Act of 1962. The majority of these operators were foreigners doing business in Nigeria. These operators' foreign exchange currencies were stored in their foreign banks, and they operated as agents for local exporters. Agricultural exports accounted for the majority of foreign exchange receipts during this time period. The Nigerian currency at the time was the pound, which was linked to the British pound to facilitate conversion. However, this slowed the establishment of a vibrant foreign exchange market. The Central Bank of Nigeria (CBN) was created in 1958, and the CBN centralized the foreign exchange market. Nigeria experienced an oil boom in the 1970s, which resulted in a significant increase in foreign exchange receipts. During this time, many imports were made using the Inward Bill for Collection, which allowed imports to be made using acceptance bills with a maturity of 90 days or more. These bills were paid in local currency, but they were supposed to be remitted in foreign currencies.

Since the immediate post-independence period until now, Nigeria's exchange rate policies have undergone significant transformations, from when the country maintained a fixed parity with the British pound, through the 1970s during the oil boom, following the economy's near collapse between 1982 and 1985, and to 1986 with the adoption of the floating exchange rate system. The political and economic reasons that underpin exchange rate policy had ramifications for the structural evolution of 


\section{Effect of Exchange Rate Fluctuation and Foreign Reserves on Macroeconomic Performance in Nigeria}

the balance of payments, the economy, inflation, and real income in each of these epochs (Dada \& Oyeranti, 2012). In Nigeria, the most prevalent floating exchange rate system is a managed floating exchange rate regime with a strong commitment to defending any particular parity. The monetary authorities have tried as much as they can to allow market forces of demand and supply to determine the exchange rates in the country since the introduction of the SAP up until now, which is an important point to note about the changes in the foreign exchange market since the introduction of the SAP up until now.

The interbank foreign exchange market system was reinstated in February 2015. This system allowed interbank foreign exchange transactions to take place in a way that permitted participants to respond freely to market signals. The Central Bank of Nigeria (CBN) began a weekly foreign exchange intervention in the foreign exchange market in February 2017 in order to maintain and regulate exchange rates within acceptable levels. According to Richard (2018), the Central Bank of Nigeria intervened in the foreign exchange market for $\$ 23.2$ billion between February 2017 and July 2018. This intervention is carried out in the market by selling and purchasing foreign exchange. Through selected institutions, the CBN sells foreign exchange directly to end customers at current autonomous selling prices. The CBN's attempt to overcome the economic issues of maintaining a stable currency rate policy in Nigeria has failed (Richard, 2018).

\section{Foreign Reserves in Nigeria}

Foreign reserves were primarily made up of gold and, on occasion, silver when the bank was established. However, following WWII, the Bretton Woods System established the US Dollar as a reserve currency, allowing it to be included in any country's official international reserves. The Federal Reserve System made it easy to exchange the US Dollar into gold from 1944 until 1968. However, no central bank was able to convert US dollars to gold from official gold reserves after 1968. No organization or individual was able to convert US Dollars into gold from government gold reserves for several years after 1973. Since 1973, no major currencies have been able to convert their reserves of gold into gold. Institutions and individuals must now purchase gold on private markets in the same way they would other commodities. Despite the fact that the US dollar and a few other currencies are no longer convertible into gold, they continue to serve as official international reserves. The currency diversification of external reserves refers to Central Banks' shift away from traditional gold reserve assets and toward a basket of foreign currencies and/or securities. Economic, historical, and political factors all influence the monetary authorities' decision on which basket of foreign currencies to hold. The correlation of currencies in the foreign exchange market, the relative stability of the reference currency, and the size of the reference currency in the home country's external trade are some other factors that influence the composition of a country's foreign reserves (Danladi, 2009). Although a general and common economic objective of currency diversification of reserves is for the Central Bank to invest in foreign currencies and securities in order to maximize the returns on financial resources, monetary authorities sometimes overlook the profitability aspect in favor of their liquidity needs, particularly if they are experiencing disequilibrium.

\section{Theories}

The Purchasing Power Parity Theory assumes that the quotient of both countries' purchasing power determines the purchasing power parity between any two currencies. Factors such as transportation costs, insurance, and other fees, however, alter this equivalency. There are three fundamental assumptions in this theory: there are no transportation costs connected with carrying commodities from one country to another, no currency conversion expenses, and no trade obstacles or quotas between the two countries. There are two variants of this theory: an absolute version and a relative version. According to the absolute version of the purchasing power parity theory, the exchange rate between two countries should represent the relationship between their local currencies' internal buying power. This means that the rate of exchange should be equal to the cost of purchasing a specific set of goods in the domestic or home country versus how much or what it would cost in a foreign country. The relative version of purchasing power parity aims to explain why the equilibrium exchange rates between two countries' currencies shift. Changes in the equilibrium exchange rates are linked to changes in the purchasing power parities of currencies in this edition. The relative version suggests that relative changes in two countries' price levels between a base and current period have a significant impact on currency exchange rates in the base and current periods.

Model of Buffer Stock: A buffer stock is a strategy for accumulating excesses over time in order to avoid swings. A buffer stock model is one in which reserves are amassed and released into the economy when demand for these reserves is high, or where the monetary authorities accumulate more reserves when supply of foreign reserves exceeds demand. This is done to keep pricing stable and eliminate unneeded volatility. According to Danladi (2009), monetary authorities choose a reserve stock that balances the opportunity cost of external reserve accumulation with the potential macroeconomic adjustment costs incurred in the absence of reserves, and the main reason why countries hold foreign exchange reserves is to smooth unpredictable and temporary imbalances in international payments. Foreign reserves, according to this idea, are an inventory of money that may be utilized to stabilize the economy during periods of macroeconomic shocks. The majority of Nigeria's foreign reserves are derived from oil. 


\section{Effect of Exchange Rate Fluctuation and Foreign Reserves on Macroeconomic Performance in Nigeria}

Because the international oil market is extremely volatile, the CBN intervenes in the foreign exchange market to buy and sell reserves and maintain the value of the local currency. This methodology aids in maintaining price stability, avoiding foreign reserve shortages, and meeting inflationary targets.

\section{Empirical Review}

Adelowokan, Adesoye, and Balogun (2015) used the ADF test for stationarity and the error correction technique to investigate the impact of exchange rate fluctuation on economic growth and investment in Nigeria from 1986 to 2014. GDP, investment, exchange rate, interest rate, and inflation are among the variables used. The findings revealed a negative association between exchange rate volatility and investment and economic growth, as well as a positive relationship between inflation, interest rates, and exchange rate. They advised that Nigeria implement a sound exchange rate management system to help the country thrive economically.

Ali, Omotosho, Ajibola, and Adele (2015) looked at the influence of the naira's actual exchange rate mismatch on Nigeria's economic growth. They used data from quarterly surveys from 2000 to 2014. The departure of the real exchange rate from a sustainable equilibrium path, estimated using the behavioral equilibrium exchange rate technique, was used to calculate the estimate of the real exchange rate misalignment. The analysis found that the actual exchange rate misalignment has a detrimental influence on Nigeria's economic growth. They advised that a market-based exchange rate arrangement be used indefinitely to ensure that the Naira's exchange rate follows a path of long-term stability.

Amassoma and Odeniyi (2016) also looked into the relationship between Nigerian economic growth and currency rate fluctuations. In order to investigate this nexus, researchers used the Johansen test for co-integration and the error correction model technique. In both the short and long run, the results demonstrated a positive but insignificant link between exchange rate variations and economic growth in Nigeria.

In a recent study, Richard (2018) looked at the relationship between the foreign exchange rate and the Nigerian economy from 1986 to 2018. His main goal was to figure out how the Nigerian economy and the foreign exchange rate are linked. In order to determine this link, he used a theoretical framework. Interest rates, external reserves, oil output, foreign direct investment, oil price index, inflation rate, terms of trade, diaspora remittances, purchasing managers' index, and foreign public debts all have a direct impact on the rate of exchange in Nigeria, according to him. According to his findings, there is a link between Nigeria's macroeconomic indicators and the foreign exchange rate. The monetary authorities should pursue a stable foreign exchange rate policy, he suggested. Furthermore, both the monetary and fiscal authorities should be encouraged to collaborate and ensure that leakages from the external reserves account are prevented, as well as that the determinants of exchange rate that have a positive relationship with some macroeconomic variables are closely monitored.

For the period 1985 to 2016, Akindele (2018) investigated the efficacy of the Nigerian foreign exchange market. He used secondary time series data and analyzed it with two equations, while estimating it with the fully modified OLS technique. His research found that GDP, oil prices, interest rates, and inflation rates all have a significant and positive relationship with the Nigerian exchange rate, whereas broad money supply has a negative relationship with the Nigerian exchange rate. He came to the conclusion that Nigeria's foreign exchange rate market was inefficient, and that the country's monetary authorities should ensure transparency in determining exchange rates in order to reduce the risks associated with exchange rate fluctuations.

Umeora (2013) looked into the impact of accumulating external reserves on Nigeria's exchange rate and inflation. He based his findings on secondary data from the CBN statistical bulletins. To determine the effect of external reserves accumulation on inflation and exchange rates, he used a simple linear regression model. The regression results showed a negative relationship between external reserves accumulation and the exchange rate in Nigeria, but a positive relationship between inflation and external reserves accumulation in Nigeria. He also noted that the money supply in Nigeria was a factor in the country's inflation. He suggested that the government ensure the best possible use and management of the country's foreign reserves.

Nwosa (2017) attempted to examine the relationship between external reserves and economic growth in Nigeria from 1981 to 2014 in a study. The dependent variable was GDP, while the independent variables were gross fixed capital formation, labor force, foreign reserves, and exchange rate. He did his analysis with time series data and the ordinary least squares method. His findings demonstrated a favorable and statistically significant association between external reserves and economic growth. To foster stronger economic growth, he suggested that Nigeria's external reserves be sensibly maintained. He also suggested that policies to stimulate the accumulation of external reserves be investigated and implemented.

Bassey, Mba, and Abraham (2019) used quarterly data from the third quarter of 2011 through the first quarter of 2019 to investigate the relationship between reserve buildup and economic growth in Nigeria. They used a non-linear ARDL technique to look at the variables' unbalanced long and short term relationships. The results of the bound test analysis indicated that the 


\section{Effect of Exchange Rate Fluctuation and Foreign Reserves on Macroeconomic Performance in Nigeria}

variables are co-integrated. According to the findings of their research, there is a link between reserve buildup and economic growth in Nigeria.

Using the ARDL technique, Elijah (2020) investigated the link between trade and foreign reserves in Nigeria from 1981 to 2017. Their findings revealed that non-oil exports, oil exports, and the exchange rate all had a positive impact on Nigeria's foreign reserves, whilst non-oil and oil imports had a negative impact. However, according to the Granger-causality result, a unidirectional relationship exists between oil exports, exchange rate, non-oil exports, and oil imports and external reserves, whereas a bidirectional relationship exists only between external reserves and non-oil imports. They recommended that goods that can be produced locally be discouraged from being imported, and that the country's reserves be well managed.

Using the ARDL approach, Adekunle (2020) investigated the relationship between external reserves and economic growth in Nigeria from 1986 to 2018. The presence of co-integration among the variables was indicated by the co-integration result. The ARDL result indicated that exchange rate and economic growth have a positive relationship while a negative relationship existed between trade openness, inflation and economic growth. The Granger-causality test also suggested that a bidirectional relationship exists between economic growth and exchange rate.

\section{METHODOLOGY}

This study employed time series data for the period 1980 to 2019. It utilizes secondary data obtained from the World Bank Development Indicators, the National Bureau of Statistics and the Central Bank of Nigeria's statistical bulletins.

Model Specification

$E D B T=(R E S V, E X R, E D S, G E X)$

$E D B T=\alpha_{0}+\alpha_{1} R E S V+\alpha_{2} E X R+\alpha_{3} E D S+\alpha_{4} G E X+£$

Where;

$$
\begin{aligned}
& \text { EDBT }=\text { External Debt } \\
& \text { EXR }=\text { Exchange Rate } \\
& \text { RESV }=\text { Reserves } \\
& \text { EDS }=\text { External Debt Servicing } \\
& \text { GEX }=\text { Government Expenditure }
\end{aligned}
$$

And $\alpha_{0}$ is the intercept. $\alpha_{1}, \alpha_{2}, \alpha_{3}$ and $\alpha_{4}$ are the parameters and $f$ is the error term.

\section{RESULTS AND DISCUSSION OF FINDING}

\section{Stationarity Test}

Augmented Dickey Fuller (ADF) unit root test was used to determine whether the variables are stationary at levels or not. If the Augmented Dickey-Fuller test statistic is greater than the Mackinnon test critical value at the level of significance of (5\%), it implies that the series is stationary at that given level. The Augmented Dickey Fuller (ADF) result of the unit root test revealed that most of the variables are stationary at first difference with inflation, credit to private sector and external debt service being stationary at level. This shows that the variables are of mixed order of integration and so, the ARDL method of estimation is the most appropriate

\section{Co-integration Test}

The ARDL Bounds test for co-integration was used to determine if any form of long run relationship exists among the variables depending on the F-Statistic value as compared to the upper and lower bounds.

Table 1: ARDL Bounds co-integration test

\begin{tabular}{cll}
\hline Test Statistic & Value & $\mathrm{k}$ \\
F-statistic & 4.322321 & 4 \\
& Critical Value Bounds & \\
Significance & 10 Bound & I1 Bound \\
$10 \%$ & 2.41 & 3.54 \\
$5 \%$ & 2.73 & 4.11 \\
$1 \%$ & 3.72 & 5.01 \\
\hline
\end{tabular}

Source: Computation from E-views (2021) 


\section{Effect of Exchange Rate Fluctuation and Foreign Reserves on Macroeconomic Performance in Nigeria}

The ARDL bounds tests has its F-statistic value given as 4.22321. This value is greater than the upper bound i.e., I1 bound at the 5 per cent level of significance. Therefore, the null hypothesis that no long run relationship exists among the variables is rejected and it is concluded that cointegration exists among the variables. With this, the long and short run models are estimated.

Table 2: ARDL Co-integrating and Long Run

Dependent Variable: LNEDBT

Selected Model: $\operatorname{ARDL}(2,2,0,2,3)$

\section{Short run Coefficient / Model}

Variable

$\mathrm{D}($ LNEDBT(-1))

$\mathrm{D}($ LNEXR)

$\mathrm{D}(\operatorname{LNEXR}(-1))$

D(LNRES)

D(LNEDS)

D(LNEDS(-1))

$\mathrm{D}($ LNGEX)

$\mathrm{D}(\operatorname{LNGEX}(-1))$

D(LNGEX(-2))

CointEq(-1)

Cointeq $=$ LNEDBT

$-0.1170 *$ LNGEX +22.2086 )

Variable
Coefficient

Std. Error

0.283180

0.092569

0.141614

0.049011

0.050418

0.033367

0.056298

0.069156

0.055198

0.189628
t-Statistic

$\begin{array}{lll}0.170744 & 1.658507 & 0.1114 \\ 0.075802 & 1.221186 & 0.2349 \\ 0.068285 & 2.073869 & 0.0500\end{array}$

0.171810

0.8652

0.5608

0.1078

0.1965

0.0881

0.0000

0.0332

$\begin{array}{ll}-5.566569 & 0.0000 \\ -2.271475 & 0.0332\end{array}$

Prob.

$-1.676692$

$-0.430736$

$-(0.2364 *$ LNEXR + 0.0195*LNRES + 0.1455*LNEDS

Long Run Coefficients

\begin{tabular}{lrrrr} 
Variable & Coefficient & Std. Error & t-Statistic & Prob. \\
& & & & 0.0002 \\
LNEXR & 0.236448 & 0.052383 & 4.513802 & 0.8681 \\
LNRES & 0.019549 & 0.116332 & 0.168048 & 0.2164 \\
LNEDS & 0.145546 & 0.114357 & 1.272738 & 0.0672 \\
LNGEX & -0.116955 & 0.060737 & -1.925593 & 0.0000 \\
C & 22.208612 & 2.722501 & 8.157429 & \\
\hline R squared & 0.933715 & F-statistic & 23.83841 Durbin Watson stat 2.270216 &
\end{tabular}

Source: Computation from E-views (2021)

The $R$ squared for the influence of foreign reserves and exchange rate on external debt in Nigeria is 0.933715 , meaning that changes in exchange rate, reserves, external debt service, and government expenditure account for around $93 \%$ of variations in external debt. Furthermore, given the probability value of the F-statistics, it can be observed from the foregoing finding that all the independent factors jointly affect external debt. The $\mathrm{R}$ squared value is greater than the Durbin Watson statistic value of 2.270216 , which is within the permissible range. At the $5 \%$ level of significance, the error correction coefficient is negative and statistically significant. This indicates that the rate of adjustment to long-run equilibrium is approximately $45 \%$.

External debt in the lag period has a positive link with external debt in the present period in the short run. Both the current and lagged exchange rates have a positive relationship with external debt. This means that a $1 \%$ increase in the exchange rate, i.e. a currency depreciation, will result in an increase in external debt. A priori expectations are met in this partnership. Reserves have a positive but insignificant relationship with external debt in the current period. However, the impact is negligible. This relationship, on the other hand, does not meet a priori expectations. This relationship could be explained by the fact that the reserves amassed are not put to productive use, resulting in the accumulation of external debt to finance economic activities. In Nigeria, the service of external debt has a negative and insignificant relationship with external debt. This means that as the cost of servicing external debt rises, Nigeria's external debt will decrease. However, this effect is minor. Government spending has a 


\section{Effect of Exchange Rate Fluctuation and Foreign Reserves on Macroeconomic Performance in Nigeria}

negative relationship with external debt in the current and second lagged periods. However, in the first period lag, this relationship is positive, implying that as government expenditure rises, external debt rises as well, as external debt is used to finance economic activities.

External debt in Nigeria has a negative association with currency rate, reserves, and external debt service in the long run. In Nigeria, however, government spending has a positive connection with external debt. In the long run, all variables except the exchange rate, which has a negative connection with external debt, comply to apriori predictions.

Table: 3 Pairwise Granger Causality Tests

\begin{tabular}{lccc}
\hline Null Hypothesis: & Obs & F-Statistic & Prob. \\
\hline EDS does not Granger Cause EDBT & 39 & 1.42010 & 0.2707 \\
EDBT does not Granger Cause EDS & & 4.26201 & 0.0207 \\
EXR does not Granger Cause EDBT & 39 & 2.71002 & 0.0690 \\
EDBT does not Granger Cause EXR & & 0.13019 & 0.8714 \\
RES does not Granger Cause EDBT & 39 & 0.52531 & 0.5789 \\
EDBT does not Granger Cause RES & & 2.50902 & 0.0967 \\
LNGEX does not Granger Cause EDBT & & & 0.0082 \\
EDBT does not Granger Cause LNGEX & 39 & 5.60829 & 0.1226
\end{tabular}

Source: from E-views (2021)

The granger causality test reveals that external debt Granger Causes external debt service while external debt servicing does not Granger Cause external debt. Also, government expenditure Granger Causes external debt while external debt does not Granger Cause government expenditure. These are the only cases of a unidirectional relationship according to the Granger causality test. Between exchange rate and external debt as well as reserves and exchange rate, a relationship of no Granger causality exists i.e., neither does exchange rate or reserves Granger Causes external debt nor does external debt Granger Causes exchange rate or reserves.

\section{CONCLUSION/RECOMMENDATION}

The purpose of this study is to see if there is a causal relationship between foreign reserves and the Nigerian exchange rate, as well as to see if the continuing buildup of foreign reserves is advantageous to the Nigerian economy. Exchange rate Granger causes foreign reserves in Nigeria, while foreign reserves do not granger cause exchange rate. This means that as the exchange rate depreciates or appreciates, it always has an impact on Nigeria's foreign reserves. This is due to the fact that Nigeria uses a managed float exchange rate regime, in which the Central Bank intervenes in the foreign currency rate market to maintain exchange rate stability. As a result, a decrease in reserves will result from an exchange rate depreciation, whereas an increase in reserves will result from an exchange rate appreciation. The Central Bank of Nigeria should pursue a steady foreign exchange rate strategy. Nigeria's monetary authorities should ensure that the determination of currency rates in the foreign exchange rate market is transparent. The government should ensure that the country's foreign reserves are used and managed efficiently. This is because it has been established that foreign reserves have a beneficial impact on economic growth and stimulate the influx of foreign direct investment, both of which help to enhance the Nigerian economy.

\section{REFERENCES}

1) Adelowokan, O. a. (2015). Exchange rate volatility on investment and growth in Nigeria: an empirical analysis. Global journal of management and business research, 21-30

2) Akindele, O. O. (2018). Foreign Exchange Market Efficiency in Nigeria (The Past and Current Exchange Rate Returns). Sumerianz Journal of Economics and Finance, 1 (1), 14-21.

3) Ali, A. I. (2015). Real exchange misalignment and growth in Nigeria. CBN Journal of Applied Statistics, Vol. 6, No. 2. 


\section{Effect of Exchange Rate Fluctuation and Foreign Reserves on Macroeconomic Performance in Nigeria}

4) Amassoma, D. a. (2016). The nexus between exchange rate variation and economic growth. Singaporean Journal of Business Economics and Management Studies, Vol. 4, No. 12, pp 7-28

5) Bassey, K. J. (2019). On economic growth - reserves accumulation nexus in Nigeria: a nonlinear asymmetric co-integration estimation. West African Journal of Monetary and Economic Integration, Vol. 19, No. 1

6) Bayat, T. M. (2014). Exchange rates and foreign exchange reserves in Turkey: nonlinear and frequency domain causality aproach. Theoretical and Applied Economics, Vol XXI, No. 11(600(, pp. 27-42

7) Dada, E. A. (2012). Exchange Rate and Macroeconomic Aggregates in Nigeria. Journal of Economics and Sustainable Development, Vol.3, No.2.

8) Danladi, J. (2009). External Reserves and Macroeconomic Performance. Ibadan: Unpublished Masters Thesis. University of Ibadan. Ibadan.

9) Elijah, A. O. (2020). Ardl-Bound Testing Approach to the Connection Between External Reserve And Economic Growth In Nigeria. Journal of Academic Research in Economics, 12(2).

10) Folorunsho, M., Ajisafe, R. A. \& Olofin, O. P. (2019). Capital controls, entrepreneurship and economic growth in selected developing countries. Asian Economic and Financial Review, 9(2):191-212.

11) Igbanugo, I. C. \& Eze, E. A. (2017). Empirical Analysis of Exchange Rate Regime and External Reserves Accumulation in Nigeria (1970-2015) . , International Journal of Research in Management, Economics and Commerce, Volume 07 Issue 07 , Page 69-79

12) IMF. (2009). International Monetary Fund, Annual Report. Retrieved from www.imf.org/external/pubs/ft/ar/2009/eng/pdf/a1.pdf

13) International Monetary Fund. (2014). BPM6 Compiltion Guide. Washington DC, USA: International Monetary Fund, Publication Services

14) Kalu, E. U., Ugwu, O. E., Ndubuaku, V. C. \& Ifeanyi, O. P. (2019). Exchange Rate and Foreign Reserves Interface: Empirical Evidence from Nigeria. The Economics and Finance Letters, Vol. 6, No. 1, pp. 1-8 .

15) Nwachukwu, N. E., Ali, A. I., Abdullahi, I. S., Shetimma, M. A., Zirra, S. S., Falade, B. S. \& Alenyi, M. J. (2016). Exchange Rate and External Reserves in Nigeria: A Threshold Cointegration Analysis . CBN Journal of Applied Statistics, Vol. 7 No

16) Nwosa Philip. (2017). External reserves and economic growth in Nigeria. Journal of Entrepreneurship, Business and Economics, 110-126

17) Nwosa Philip. (2017). External reserves and economic growth in Nigeria. Journal of Entrepreneurship, Business and Economics, 110-126

18) Onwuka, M. E. (2014). Impact of External Reserve and Foreign Debt on Naira Exchange Rate. Journal of International Academic Research for Multidisciplinary, Volume 2, Issue 6

19) Osuka, B. a. (2008). Foreign Exchange Fluctuations and the Nigeria Fledging Economy. The Nigerian Banker.

20) Raju, J. V. \& Gokhale, M. S. (2013). Causality between Exchange Rate and Foreign Exchange Reserves in the Indian Context . Global Journal of Management and Business Research Finance, Vol.13, Issue 7 Version 1.0 .

21) Richard, C. O. (2018). Foreign Exchange Rate Nexus and the Nigeria Economy: A Theoretical Perspective, $1986-2018$. European Journal of Accounting, Finance and Investment, Vol. 4, No. 12

22) Umeora, C. E. (2013). Accumulation of External Reserves and Effects on Exchange Rates and Inflation in Nigeria. International Business and Management, Vol. 6, No. 2, 2013, pp. 105-114 